\title{
Peran Kepala Sekolah Sebagai Edukator Untuk Meningkatkan Mutu Lulusan Di SMA Negeri I Muara Bungo
}

\author{
Hamirul \\ hrul@ymail.com \\ Program Studi llmu Administrasi Negara \\ Sekolah Tinggi Ilmu Administrasi Setih Setio
}

\begin{abstract}
This study aims to determine the role of the principal of SMA 1 Muara Bungo in maintaining the quality of graduates by using descriptive methods and qualitative approaches with 15 informants consisting of 10 teachers and 5 students of class XII using triangulation generated by the principal's policy in improving the quality of his role as an educator graduating students include: Implementing the teaching and learning process routinely, evaluating routinely, holding additional learning, carrying out Try Out activities. Obstacles faced by school principals in improving the quality of graduation of students are: Funding, Human Resources, Lack of motivation of students to participate in additional learning activities, Students are less serious in participating in additional learning activities. Efforts made by principals in improving the quality of student graduation include: Making control cards for students participating in afternoon tutoring activities, Motivating students on the importance of additional learning activities, Creating learning programs that are creative, innovative, and conducive, Raising funds from student guardians .
\end{abstract}

Keywords: Principal, Educator, Quality of Graduates.

\begin{abstract}
Abstrak
Peneltian ini bertujuan untuk mengetahui peran kepala sekolah SMA Negeri 1 Muara Bungo dalam menjaga mutu lulusan dengan menggunakan metode deskriptif dan pendekatan kualitatif dengan informan sebanyak 15 orang yang terdiri dari 10 orang guru dan 5 orang siswa kelas XII dengan menggunakan trianggulasi dihasilkan Kebijakan kepala sekolah dalam meningkatkan kualitas perannya sebagai edukator kelulusan siswa antara lain : Melaksanakan proses belajar mengajar secara rutinitas, Penilaian secara rutinitas,Mengadakan belajar tambahan, Melaksanakan kegiatan Try Out. Hambatan yang dihadapi kepala sekolah dalam meningkatkan kualitas kelulusan siswa adalah : Pendanaan, Sumber daya Manusia, Kurangnya motivasi siswa untuk mengikuti kegiatan belajar tambahan, Siswa kurang serius mengikuti kegiatan belajar tambahan. Upaya yang dilakukan kepala sekolah dalam meningkatkan kualitas kelulusan siswa, antara lain : Membuat kartu control siswa/siswi yang ikut kegiataan les sore,Memotivasi siswa akan pentingnya kegiatan belajar tambahan,Membuat program pembelajaran yang kreatif, inovatif, dan kondusif, Menggalang dana dari wali murid.
\end{abstract}

Kata Kunci: Kepala Sekolah, Edukator, Mutu Lulusan.

\section{PENDAHULUAN}

Pada perkembangan peradaban kehidupan manusia, pendidikan memiliki arti yang sangat penting. Segala macam ilmu pengetahuan dan kemajuan teknologi yang dirasakan saat ini adalah salah 
satu bentuk nyata dari upaya pendidikan yang dilakukan manusia. Oleh karena itu, pendidikan dapat dipahami sebagai suatu upaya yang dilakukan seseorang melalui proses belajar guna memperoleh ilmu pengetahuan yang berguna bagi pengembangan dirinya dan kemajuan peradaban kehidupannya di masa sekarang dan dimasa yang akan datang. Salah satu agenda reformasi di bidang pendidikan adalah pendelegasian kewenangan pengelolaan pendidikan pada pemerintah daerah, sebagaimana UU No. 23 tahun 2014. UU tersebut menyebutkan bahwa yang akan menjadi kewenangan pemerintah daerah tidak sepenuhnya yaitu terbatas pada aspek pembiayaan, sumberdaya manusia dan sarana dan prasarana. Sementara untuk aspek-aspek menyangkut kurikulum, pemebelajaran, metode dan waktu belajar, buku serta alokasi belanja dan penggunaan anggaran, semuanya menjadi kewenangan sekolah. Oleh karena itu kepala sekolah dan para guru dituntut bertanggung jawab terhadap kualitas proses dan hasil belajar guna meningkatkan mutu pendidikan secara nasional (Rosyada, 2013).

Di Indonesia, pendidikan juga memiliki arti penting sebagaimana terkandung dalam pembukaan UUD 1945 pada alinea keempat, yang dinyatakan bahwa salah satu tujuan atau cita-cita bangsa Indonesia adalah ikut dalam mencerdaskan kehidupan bangsa. Pernyataan tersebut dapat dicermati bahwa sejak dari awal pemerintah Indonesia sudah memprioritaskan kemajuan sumber daya manusia Bangsa Indonesia yang tentunya diwujudkan melalui proses pendidikan. Hakikat pendidikan diartikan sebagai kepuasan secara konseptual terhadap kenyataan kehidupan manusia. Baik disadari maupun tidak disadari manusia telah melaksanakan pendidikan mulai dari keberadaan manusia pada zaman primitif sampai jaman moderen, bahkan selama masih ada kehidupan manusia di dunia, pendidikan akan tetap berlangsung. Kesadaran akan konsep tersebut menunjukkan bahwa pendidikan sebagai gejala kebudayaan. Artinya sebagai tanda bahwa manusia sebagai makhluk budaya yang salah satu tugas kebudayaan itu tampak pada proses pendidikan.

Pendidikan dapat dibedakan menjadi pendidikan formal, nonformal, dan informal. Pendidikan formal adalah jalur pendidikan yang terstruktur dan berjenjang yang terdiri atas pendidikan dasar, pendidikan menengah, dan pendidikan tinggi. Kemudian, pendidikan nonformal adalah jalur pendidikan di luar pendidikan formal yang dapat dilaksanakan secara terstruktur dan berjenjang. Sedangkan pendidikan informal adalah jalur pendidikan keluarga dan lingkungan. Kemudian, dalam Undang Undang No 20 Tahun 2003 tentang Sistem Pendidikan Nasional, pendidikan diartikan sebagai usaha sadar dan terencana untuk mewujudkan suasana belajar dan proses pembelajaran agar peserta didik secara aktif mengembangkan potensi dirinya untuk memiliki kekuatan spiritual keagamaan, pengendalian diri, kepribadian, kecerdasan, akhlak mulia, serta keterampilan yang diperlukan dirinya, masyarakat, bangsa, dan Negara. Dari pengertian tersebut dapat dipahami bahwa, pendidikan di Indonesia tidak hanya ditekankan pada kemampuan secara akademik semata namun lebih dari itu pendidikan juga diprioritaskan untuk menciptakan generasi yang memliki spiritual keagamaan, memiliki kepribadian dan kemampuan mengendalikan diri, berakhlak mulia, serta keterampilan yang dapat bermanfaat bagi dirinya sendiri, masyarakat, bangsa dan negara.

Untuk meningkatkan kelulusan siswa, kepala sekolah membuat kebijakan dibantu oleh guru, karyawan sekolah sangat penting. Karena upaya peningkatan kualitas lulusan peserta didik, kepala sekolah sangat penting karena merupakan motor penggerak bagi sumber daya sekolah terutama guruguru dan karyawan sekolah. Kepala sekolah bersama guru memberi tugas tambahan agar terselenggarakan proses belajar-mengajar dengan baik dan terjadinya interaksi antara guru yang memberi pelajaran dan murid yang menerima pelajaran. Sebagai orang yang mendapat tugas tambahan berarti tugas pokok kepala sekolah tersebut adalah guru yaitu sebagai tenaga pengajar dan pendidik,di sini berarti dalam suatu sekolah seorang kepala sekolah harus mempunyai tugas sebagai seorang guru yang melaksanakan atau memberikan pelajaran atau mengajar bidang studi tertentu atau memberikan bimbingan. Selain kepala sekolah, guru juga memiliki peran cukup. Kehadiran guru sebagai tenaga pendidik yang menjadi penerang tanpa batas tanpa membedakan siapa yang diteranginya. Tetapi, dalam mengemban amanah sebagai seorang guru, perlu kiranya tampil sebagai sosok profesional. Sosok yang memiliki ilmu pengetahuan dan wawasan, sosok yang dapat member 
contoh teladan dan sosok yang selalu berusaha maju. terdepan dan mengembangkan diri untuk membentuk inovasi dan bermanfaat sebagai bahan pengajaran kepada anak didik.

Guru mempunyai tugas dan kewajiban, mereka tidak hanya mengajar, mendidik dan membimbing siswa tetapi juga patut sebagai model dalam pembelajaran sehingga mampu menciptakan suasana belajar yang efektif dan menyenangkan. Di sini, guru sangat berperan penting untuk menjadi contoh sekaligus motivator dan inspirator sehingga peserta didik akan lebih tertarik dan antusias dalam belajar, sehingga hasil belajar yang didapat berdaya guna dan berhasil. Peran guru dalam meningkatkan kelulusan, terutama dalam proses belajar mengajar mampu menuntut siswa untuk aktif selama kegiatan pembelajaran. Dalam hal ini, guru seharusnya mampu mengkombinasikan metode mengajar. Penggunaan metode mengajar harus disesuaikan dengan mata pelajaran yang akan disampaikan, sehingga tercipta suasana belajar yang aktif, dan inovatif. SMA Negeri 1 Muara Bungo, merupakan salah satu Sekolah Menengah Atas Negeri yang ada di Kabupaten Bungo, Provinsi Jambi, indonesia. Sama dengan SMA pada umumnya di Indonesia, masa pendidikan sekolah di SMAN 1 Muara Bungo ditempuh dalam waktu tiga tahun pelajaran, mulai dari Kelas X sampai Kelas XII. SMA Negeri 1 Muara Bungo termasuk ke dalam pendidikan formal karena terdapat bentuk pendidikan atau pelatihan yang diberikan secara terorganisasi dan berjenjang, baik bersifat umum atau khusus.

Upaya meningkatkan kualitas kelulusan siswa kepala sekolah membuat beberapa kebijakan mulai dari mengadakan les bagi siswa terutama bagi mata pelajaran yg di Ujian Nasional, menugaskan seorang guru untuk membimbing siswa belajar, bekerja sama dengan komite sekolah untuk menambah jam ngajar dengan dibayar insentif yang seimbang dan melakukan evaluasi terhadap siswa tentang kekurangan terhadap suatu mata pelajaran. Dari berbagai kebijakan yang dibuat oleh kepala sekolah juga mengalami masalah dalam meningkatkan kelulusan siswa SMA Negeri 1 Muara Bungo mulai dari kurangnya keikutsertaan siswa kelas XII dalam penambahan jam pelajaran diluar dari jam pelajaran wajib atau les setelah pulang dari sekolah, masih adanya beberapa guru yang datang terlambat saat proses belajar mengajar dimulai dan beberapa siswa belum memiliki buku pegangan untuk setiap mata pelajaran.

Target kelulusan 100\% membuat siswa dan guru tidak bisa sedikit santai dalam mengikuti proses pembelajaran. (Muh. Fitrah, 2017) menyatakan bahwa peranan kepala sekolah dalam rangka meningkatkan mutu pendidikan sangatlah penting karena dapat mempengaruhi berhasilan atau tidaknya mutu pendidikan itu sendiri. Secara garis besar, ruang lingkup tugas kepala sekolah dapat diklasifikasikan ke dalam dua aspek pokok, yaitu pekerjaan dibidang administrasi sekolah dan pekerjaan yang berkenaan dengan pembinaan professional pendidikan. Adapun peran kepala sekolah dalam meningkatkan mutu pendidikan, yang meliputi perannya sebagai educator, manager, administrator, supervisor, leader, innovator, dan motivator (Mulyasa; Vivi, 2013).

Kepala sekolah sebagai educator yaitu kepala sekolah bertugas untuk membimbing guru, tenaga kependidikan, siswa, mengikuti perkembangan iptek, dan memberi teladan yang baik. Seperti pemaparan Vivi (2013) bahwa untuk menciptkan iklim sekolah yang kondusif diperlukan kerjasama atau hubungan yang harmonis antara seluruh warga sekolah dan tidak hanya menjadi tanggung jawab kepala sekolah semata. Oleh karena itu upaya yang dapat dilakukan kepala sekolah dalam meningkatkan kinerja sebagai educator, khususnya dalam peningkatan kinerja sebagai educator, khususnya dalam peningkatan kinerja tenaga kependidikan dan prestasi belajar peserta didik adalah mengikutsertakan guru-guru dalam pendidikan lanjutan dengan cara mendorong para guru untuk memulai kreatif dan berprestasi.

Kepala sekolah sebagai manager yaitu mempunyai fungsi menyusun perencanaan, mengkoordinasikan kegiatan, melakukan pengawasan, melakukan evaluasi terhadap kegiatan, mengadakan rapat, mengambil keputusan, mengatur proses pembelajaran, mengatur administrasi, dan mengatur tata usaha, siswa, ketenagaan, sarana dan prasarana, keuangan (Sabirin, 2012). Sunarto (2011) menjelaskan bahwa kepala sekolah sebagai manajer dituntut memiliki kesiapan untuk mengelola sekolah, kemampuan dan kemauan muncul manakala para pemimpin sekolah dapat membuka diri 
secara luas untuk menyerap sumber-sumber yang dapat mendorong perubahan manajerial. Untuk melakukan peran dan fungsinya sebagai manajer, kepala sekolah harus memiliki strategi yang tepat untuk memberdayakan tenaga kependidikan melalui kerjasama, memberi kesempatan kepada para tenaga pendidikan untuk meningkatkan profesinya dan mendorong keterlibatan seluruh tenaga kependidikan yang menunjang program sekolah. Karena jika merujuk pada pandangan manajemen modern, kerjasama merupakan hal yang amat mendasar dalam sebuah organisasi.

Kepala sekolah sebagai administrator yaitu kepala sekolah bertanggung jawab atas segala kelancaran segala pekerjaan dan kegiatan administrative di sekolahnya. Sunarto (2011) memaparkan bahwa kepala sekolah sebagai kategori administrasi pendidikan perlu melengkapi wawasan kepemimpinan pendidikan dengan pengetahuan dan sikap yang antisipatif terhadap perubahan yang terjadi dalam kehidupan masyarakat, termasuk kebijakan pendidikan. Sebagai seorang administrator, kepala sekolah harus memiliki kemampuan untuk memperbaiki dan mengembangkan semua fasilitas sekolah. Secara spesifik kepala sekolah juga dituntut untuk mengelola kurikulum, mengelola adminsitrasi sarana dan prasarana, mengelola adminsitrasi kearsipan, dan mengelola administrasi keuangan (Purwanti, 2013). Manajemen keuangan dapat diartikan sebagai tindakan pengurusan keuangan seperti pertanggung jawaban dan pelaporan (Vivi, 2013).

Kepala sekolah sebagai Supervisor. Supervisor adalah kegiatan mengamati, mengidentifikasi mana hal-hal yang sudah benar, mana yang belum benar, dan mana pula yang tidak benar, dengan maksud agar tepat dengan tujuan memberikan pembinaan (Arikunto, 2004); Barinto, 2012; Vivi (2013). A.R. Manarus dan Sidik (1996) ada hubungan positif yang signifikan antara supervise kepala sekolah dan kepuasan kerja gur (Fanani, Mardapi \& Wuraji, 2014).

Kepala sekolah sebagai Leader yaitu kepemimpinan kepala sekolah merupakan salah satu faktor yang mendorong sekolah dapat mewujudkan visi, misi dan tujuan dan sasaran sekolah melalui program- program yang dilaksanakan secara terencana dan bertahap. Karena itu kepemimpinan adalah kegiatan mempengaruhi orang lain agar mau bekerja untuk mencapai tujuan yang telah ditentukan. Untuk kepentingan tersebut, kepala sekolah harus mampu mempengaruhi dan menggerakkan sumberdaya sekolah dalam kaitannya dengan perencanaan dan evaluasi program sekolah, pengembangan kurikulum, pembelajaran, pengelolaan ketenagaan, sarana dan sumber belajar, keuangan, pelayanan siswa, hubungan sekolah dengan masyarakat, penciptaan iklim sekolah, dan sebagainya.

Kepala sekolah sebagai Innovator, dalam melakukan peran dan fungsinya sebagai innovator, kepala sekolah harus memiliki strategi yang tepat untuk menjalin hubungan yang harmonis dengan lingkungan, mencari gagasan baru, mengintegrasikan setiap kegiatan, memberikan teladan kepada seluruh tenaga kependidikan disekolah dan mengembangkan model-model pembelajaran inovatif. Ancok (2012) memaparkan bahwa inovasi adalah suatu perubahan dari sesuatu hal, baik bersifat incremental maupun perubahan yang bersifat radikal. Peran kepala sekolah sebagai innovator akan tercermin dari cara-cara ia melakukan pekerjaannya secara konstruktif, kreatif, delegatif, integrative, rasional dan objektif, keteladanan, disipilin, serta adaptable dan fleksibel.

Kepala sekolah sebagai motivator, kepala sekolah harus memiliki strategi yang tepat untuk memberikan motivasi kepada para tenaga kependidikan dalam melakukan berbagai tugas dan fungsinya. Karena kepala sekolah meyakini dengan kemampuan membangun motivasi yang baik akan membangun dan meningkatkan efektivitas dan efesiensi kerja (Sabirin, 2012; Purwanti, 2013), sehingga bawahannya mampu berkreasi demi mewujudkan mutu pendidikan yang baik pula. Kemampuan kepala sekolah membangun motivasi menjadi salah satu kunci untuk meningkatkan mutu pendidikan yang baik pula. Kemampuan kepala sekolah membangun motivasi menjadi salah satu kunci untuk meningkatkan mutu pendidikan karena dikolaborasikan dengan kinerja guru. Hasil penelitian Septiana, Ngadiman \& Ivada (2013) menyimpulkan bahwa kepemimpinan kepala sekolah dan motivasi kerja secara bersamasama berpengaruh signifikan terhadap kinerja guru. 


\section{METODE PENELITIAN}

Penelitian ini menggunakan metode deskriptif dengan pendekatan kualitatif dengan informan sebanyak 15 orang yang terdiri dari pegawai dan staff Dinas Pendidikan dan Kebudayaan Kabupaten Bungo dengan menggunakan analisis deskriptif serta trianggulasi

\section{HASIL DAN PEMBAHASAN}

UU Nomor 20 tahun 2003 tentang Sisdiknas pasal 3 disebutkan bahwa " pendidikan nasional berfungsi mengembangkan kemampuan dan membentuk watak seperti peradapan bangsa yang bermartabat dalam rangka mencerdaskan kehidupan bangsa,berkembangnya potensi peserta didik agar menjadi manusia yang beriman dan bertaqwa kepada Tuhan Yang Maha Esa, Beraklak mulia, sehat, berilmu, cakap, kreatif, mandiri, menjadi warga Negara yang demokratis serta bertanggung jawab.

Upaya meningkatkan kualitas kelulusan siswa, Kepala Sekolah SMA Negeri 1 Muara Bungo, Rosdi, mengatakan bahwa "... untuk meningkatkan kualitas kelulusan siswa itu standar SKL. Pertama yaitu dasarnya adalah kurikulum 2013, ketika sudah memegang kurikulum 13,standar kelulusan itu dijabarkan dalam kkm. Kkm yang ada di SMA Negeri 1 Bungo itu adalah level 7,5,hampir seluruh mata pelajaran nilai KKMnya 7,5. Apa yang harus dilakukan untuk mencapai kkm 7,5,1). Melaksanakan proses belajar mengajar secara rutinitas, 2) melaksanakan secara rutinitas juga itu penilaian. Penilaian di K13 itu ada 3 penilaian antara lain : penilaian efektif,psikimotor,dan penilaian kognitif. Bagaimana kita untuk melaksanakan kebijakan tadi,bagaimana kelulusan itu bias nilainya meningkat,pertama memang salah satu tadi melaksanakan proses belajar mengajar secara rutinitas,penilaian secara rutinitas, kemudian kami tambahkan dengan kegiatan-kegiatan extra salah satu contohnya bekerja sama dengan lembaga pendidikan yaitu Ganesa Operational,mengadakan kegiatan les sore,dan mengadakan Try Out".

Tabel.1 Data Kelulusan Peserta Didik SMA N 1 Muara Bungo Tahun 2012-2016

\begin{tabular}{cccccc}
\hline & \multicolumn{5}{c}{ Jumlah Siswa } \\
No & Tahun & IPA & IPS & Lulus (\%) & Tidak Lulus (\%) \\
\hline 1 & $2012-2013$ & 194 & 116 & $100 \%$ & - \\
2 & $2013-2014$ & 194 & 140 & $100 \%$ & - \\
3 & $2014-2015$ & 162 & 163 & $100 \%$ & - \\
4 & $2015-2016$ & 194 & 177 & $100 \%$ & - \\
\hline
\end{tabular}

Tabel di atas merupakan kelulusan SMA N 1 Muara Bungo dari tahun ke tahun. Dimana tahun 2012-2016 angka kelulusan di SMA N 1 Muara Bungo 100\%. Menurut Yunelti “.... untuk meningkatkan kualitas kelulusan siswa kepala sekolah menetapkan beberapa kebijakan antara lain : melaksanakan kegiatan belajar tambahan, melakukan kerja sama dengan beberapa pihak untuk melaksanakan Try Out. Pendapat yang serupa juga dikatakan oleh Wiji guru kimia SMA N 1 Muara Bungo, beliau mengatakan bahwa untuk meningkatkan kualitas kelulusan siswa, kepala sekolah menetapkan beberapa kebijakan, antara lain :Melaksanakan belajar tambahan untuk kelas XII di sore hari, Melaksanakan Try Out UN". Pendapat yang sama juga disampaikan oleh Bustimar, guru matematika SMA N 1 Muara Bungo yang mengatakan bahwa"... kebijakan kepala sekolah dalam meningkatkan kualitas kelulusan siswa adalah memberi latihan soal-soal materi UN kepada siswa/siswi kelas XII, mengadakan kegiatan tambahan belajar sore pada setiap mata pelajaran yang di UN kan dan melaksanakan kegiatan Try Out UN sebelum, dan sesudah kegiatan tambahan belajar sore".

Menurut Surmiati, guru bahasa inggris SMA N 1 Muara Bungo dalam hal meningkatkan kualitas kelulusan siswa sekolah telah melakukan kegiatan-kegiatan diantaranya "...Mensosialisasikan kepada wali murid kelas XII tentang hal-hal yang berkaitan dengan pelaksanaan Ujian Nasional 2015/2016. 
Membuat program bagi seluruh guru-guru yang mengajar dikelas XII dan guru yang mau mengajar bimbel (tambahan belajar). Mensosialisasikan kepada seluruh siswa kelas XII yang mau menjalani UN 2016. Melaksanakan kegiatan bimbingan belajar tambahan pada sore hari untuk bidang studi yang akan di UN kan".

Erivariadi, guru fisika SMA N 1 Muara Bungo berpendapat".. kebijakan kepala sekolah dalam meningkatkan kualitas kelulusan siswa pada SMA N 1 Muara Bungo adalah melaksanakan beberapa program. Melaksanakan belajar tambahan pada sore hari, Mengadakan kegiatan Try Out, Bedah SKL bagi guru - guru yang mengajar pada kelas XII". Menurut Sugihartini "... untuk meningkatkan kualitas kelulusan siswa SMA N 1 Muara Bungo, kepala sekolah mengadakan kegiatan belajar tambahan sore hari yang dilaksanakan dari bulan februari sampai maret 2016 setiap hari kamis, jumat, dan sabtu. Yang kedua kebijakan kepala sekolah yaitu mengadakan kegiatan Try Out kerja sama dengan lembaga pendidikan kurang lebih 3 kali. Setiap kali Try Out di tayangkan hasilnya sehingga dapat digunakan siswa untuk memotivasi pada Try Out berikutnya". Menurut Rahayu, siswi SMA N 1 Muara Bungo jurusan IPA mengatakan bahwa"...dalam meningkatkan kualitas kelulusan siswa sekolah mengadakan tambahan jam pelajaran (les sore), sekolah juga mengadakan Try Out'.

\begin{tabular}{ccc}
\multicolumn{3}{c}{ Tabel 2. Jumlah siswa SMA N 1 Muara Bungo yang diterima di PTN dan PTS } \\
\hline No & Tahun & Jumlah siswa-siswi yang diterima di PTN dan PTS \\
1 & $2012-2013$ & 38 orang \\
2 & $2013-2014$ & 42 orang \\
3 & $2014-2015$ & 52 orang \\
\hline
\end{tabular}

Sumber : SMA N 1 Muara Bungo

Berdasarkan tabel di atas dapat disimpulkan bahwa jumlah siswa-siswi SMA N 1 muara Bungo yang diterima di PTS dan PTS pada tahun 2012-2013 sebanyak 38 orang. Tahun berikutnya jumlah yang diterima di PTN dan PTS meningkat dari tahun sebelumnya yaitu 42 orang. Pada tahun berikutnya jumlah yang diterima di PTN dan PTS sebanyak 52 orang. Dalam hal ini jumlah siswa siswi SMA N 1 Muara Bungo yang diterima di PTN dan PTS terus meningkat dari tahun ke tahun. Pendapat yang sama juga disampaikan Siska siswa SMA N 1 Muara Bungo jurusan IPA mengatakan bahwa"... untuk meningkatkan kelulusan siswa kepala sekolah mengadakan belajar tambahan seperti les sore dan juga mengadakan Try Out untuk siswa/siswi SMA N 1 Muara Bungo". Pendapat yang serupa juga dikatakan Kurnia siswa SMA N 1 Muara Bungo jurusan IPA mengatakan bahwa"... dalam meningkatkan kualitas kelulusan siswa kepala sekolah dan guru mengadakan belajar tambahan pada sore hari yang dilaksanakan setiap hari kamis, jumat, dan sabtu dan mengadakan Try Out".

Makfir siswa SMA N 1 Muara Bungo jurusan IPA berpendapat”... dalam meningkatkan kelulusan siswa kebijakan kepala sekolah adalah memberikan tuga yaitu contoh-contoh soal UN tahun lalu, supaya siswa/siswi memahami contoh-contoh soal tersebut". Sementara Yusuf siswi SMA N 1 Muara Bungo jurusan IPA dalam kesempatannya mengatakan bahwa".. kebijakan kepala sekolah dalam meningkatkan kualitas kelulusan siswa antara lain : Mengadakan kegiatan les sore pada setiap mata pelajaran yang di UN kan, Melaksanakan kegiatan Try Out UN di sekolah". Saputra siswa SMA N 1 Muara Bungo jurusan IPA berpendapat".. kebijakan kepala sekolah dalam meningkatkan kualitas kelulusan siswa adalah mengadakan belajar tambahan pada sore hari dan melaksanakan kegiatan Try Out". Pernyataan yang sama pun juga disampaikan oleh Putri siswi SMA N 1 Muara Bungo jurusan IPA mengatakan bahwa" kebijakan kepala sekolah dalam meningkatkan kualitas kelulusan siswa adalah mengadakan belajar tambahan pada sore hari dan melaksanakan kegiatas Try Out'.

Pernyataan yang serupa pun juga disampaikan oleh Alvionita siswi SMA N 1 Muara Bungo jurusan IPA mengatakan bahwa mengatakan bahwa".. kebijakan kepala sekolah dalam meningkatkan kualitas kelulusan siswa adalah mengadakan belajar tambahan pada sore hari setiap hari kamis,jumat dan sabtu. Serta melaksanakan kegiatas Try Out". "...Dalam meningkatkan kualitas kelulusan siswa 
perlu dukungan dana penunjang seperti dana BOS, dana belum cukup untuk mengatasi dalam peningkatan kualitas kelulusan siswa. Menurut Rosdi, selaku kepala sekolah SMA N 1 Muara Bungo, kendala lain yang dihadapi pertama diantaranya dana yang ada di SMA N 1 muara Bungo itu memang cukup terbatas, apalagi dana BOS tidak diperuntukkan untuk membayar yang sifatnya personal tapi sifatnya non personal. Hambatan berikutnya adalah sumber daya manusia, seperti Guru-guru di SMA N 1 Muara Bungo itu sudah banyak yang mendekati masa pensiun, akibatnya guru itu menjadi berkurang, dan tingkat kemampuan guru yang lebih muda belum memadai. Disamping itu siswa, sering terjadi ketika sedang melaksanakan kegiatan yang tujuannya untuk meningkatkan kualitas atau mutu dari ujian nasional itu, kadang-kadang siswa itu menanggapi kegiatan itu sekedar memenuhi tuntutan. Kemudian didalam kegiatan les sore, Try Out siswa-siswa itu menanggapi kegiatan itu adalah ceremonial, akibatnya hasilnya banyak yang dibawah KKM".

Menurut Yunelti Selaku guru Bahasa Indonesia, "...hambatan yang dihadapi kepala sekolah adalah kurangnya motivasi siswa untuk mengikuti kegiatan belajar tambahan". Pendapat yang serupa juga di katakan oleh Bustimar guru matematika SMA N 1 Muara Bungo mengatakan"... yang menjadi hambatan paling penting dalam meningkatkan kualitas kelulusan siswa adalah peserta didik kurang termotivasi untuk mengikuti kegiatan tambahan belajar sore sehingga ada beberapa peserta didik jarang mengikuti kegiatan tersebut". Pendapat berbeda dikemukakan oleh Erivariadi selaku guru fisika di SMA N 1 Muara Bungo mengatakan bahwa tidak ada hambatan dalam meningkatkan kualitas kelulusan siswa. Menurut Surmiati guru bahasa inggris SMA N 1 Muara bungo mengatakan bahwa hambatan yang dialami antara lain "...Masih banyak diantara siswa yang kurang serius mengikuti kegiatan bimbel sore. Masih ada diantara siswa yang merasa pesimis dalam menghadapi UN 2016 karena tidak memiliki masa depan yang jelas".

Menurut Wiji guru kimia SMA N 1 Muara Bungo ".. mengatakan bahwa yang menjadi hambatannya adalah kurang kemauan dari peserta didik itu sendiri untuk mengikuti belajar tambahan disekolah setiap hari kamis, jumat, dan sabtu".Sedangkan Sugihartini berpendapat bahwa hambatannya adalah"...Umumnya siswa kurangnya kesadaran untuk mengikuti kegiatan belajar sore, walaupun pihak sekolah sudah mengadakan. Contoh dengan memberikan absen dikelas yang diketahui orang tuanya.Umumnya siswa kurang kemauan mengikuti kegiatan les sore, dikarenakan kondisi fisiknya yang telah mengikuti kegiatan proses belajar pagi dan kegiatan di tempat lain". Menurut Rahayu siswi SMA N 1 Muara Bungo jurusan IPA mengatakan".. bahwa hambatannya adalah banyak siswa/siswi yang kurang aktif mengikuti kegiatan les sore karena kondisi fisik yang telah mengikuti kegiatan proses belajar pagi hari". Pendapat yang serupa juga disampaikan oleh Overa Siska siswi SMA N 1 Muara Bungo jurusan IPA mengatakan bahwa "...hambatannya adalah letih dikarenakan telah mengikuti proses belajar di pagi hari".

Sandi Makfir siswa SMA N 1 Muara Bungo jurusan IPA berpendapat"... bahwa masih ada siswa/siswi yang masih belum memahami contoh-contoh soal UN sebelumnya. Pendapat Kurnia siswa SMA N 1 Muara Bungo jurusan IPA mengatakan".. bahwa masih banyak siswa yang kurang serius mengikuti les sore". Sementara Yusuf siswi SMA N 1 jurusan IPA Muara Bungo mengatakan "...bahwa yang menjadi hambatan kebijakan kepala sekolah dalam meningkatkan kualitas kelulusan siswa adalah kurangnya motivasi dari siswa itu sendiri untuk mengikuti les sore sehingga ada beberapa siswa yang jarang mengikuti kegiatan les sore". Pendapat yang serupa juga disampaikan oleh Saputra siswa SMA N 1 muara Bungo jurusan IPA mengatakan".... bahwa kurangnya motivasi siswa dalam mengikuti kegiatan belajar tambahan". Putri siswi SMA N 1 Muara Bungo jurusan IPA mengatakan "..bahwa ada beberapa siswa yang kurang kemauan saat guru menjelaskan materi mata pelajaran yang di UN kan pada kegiatan les sore". Alvionita siswi SMA N 1 Muara Bungo jurusan IPA berpendapat "..hambatannya adalah kurang kemauan mengikuti kegiatan belajar tambahan di sekolah".

Upaya kepala sekolah pertama adalah melaksanakan kerja sama dengan lembaga pendidikan, lembaga pendidikan itu seperti GO. Selanjutnya agar kegiatan les sore dapat bejalan sesungguhnya, sekolah melengkapi semua administrasi, mulai dari absen, membuat kartu control untuk siswa yang ikut 
les sore. Kartu control itu dipegang oleh siswa dan setiap mata pelajaran yang disampaikan dibuat materi. Kemudian sepulang dirumah, dia menandatangani dengan wali muri/orang tua, besoknya kesekolah lagi untuk diserahkan lagi kepada guru mata pelajaran, ketika itu guru mata pelajaran melihat siswa ini hadir, siswa ini setengah hadir. Guru Bahasa Indonesia Yunelti berpendapat"... bahwa upaya yang dilakukan adalah memberi motivasi kepada siswa tentang pentingnya kegiatan belajar tambahan juga memantau absen siswa yang tidak mengikuti kegiatan belajar tambahan dan memanggil orang tua siswa yang bersangkutan jika kehadirannya kurang (jarang mengikuti) kegiatan belajar tambahan".

Pendapat yang serupa juga dikemukakan oleh Sugihartini guru biologi SMA N 1 Muara Bungo mengatakan bahwa"... upaya yang dilakukan kepala sekolah untuk meningkatkan kualitas kelulusan yaitu memotivasi siswa akan pentingnya kegiatan belajar sore untuk meningkatkan kualitas kelulusan siswa. Siswa yang tidak mengikuti kegiatan ler sore selama $3 x$ berturut - turut dipanggil orang tua, agar memberikan motivasi dan mengontrol kegiatan belajar anaknya di rumah". Menurut Bustimar guru matematika SMA N 1 Muara bungo".. upayanya membuat program pembelajaran yang kreatif, inovatif, dan kondusif untuk peningkatan prestasi dan kualitas kelulusan siswa". Menurut Surmiati guru bahasa inggris SMA N 1 Muara Bungo mengatakan bahwa upaya meningkatkan kualitas kelulusan siswa adalah selalu berupaya memberikan motivasi kepada seluruh siswa untuk menempuh UN 2016". Pendapat yang serupa juga dikatakan oleh Wiji guru kimia SMA N 1 Muara Bungo beliau mengatakan bahwa".. upayanya adalah memotivasi siswa supaya sukses dan lulus dalam kegiatan UN". Erivariadi Selaku guru Fisika SMA N 1 Muara Bungo mengatakan bahwa".. upaya kepala sekolah adalah memotivasi siswa agar mengikuti kegiatan les sore.

Menurut Rahayu siswi SMA N 1 Muara Bungo jurusan IPA berpendapat bahwa "...upayanya adalah pihak sekolah memberikan sanksi kepada siswa/siswa kela XII yang tidak mengikuti belajar tambahan pada sore hari". Pendapat yang sama juga disampaikan oleh Yuliana Overa Siska siswi SMA N 1 Muara Bungo jurusan IPA mengatakan bahwa "..pihak sekolah memberikan sanksi kepada siswa/siswa kela XII yang tidak mengikuti belajar tambahan pada sore hari. Makfir siswa SMA N 1 Muara Bungo jurusan IPA berpendapat bahwa".. upayanya adalah member penjelasan kepada siswa/siswi XII terhadap contoh-contol soal yang akan di UN kan sampai benar-benar mengerti". Pendapat yang serupa juga disampaikan oleh Agung Kurnia siswa SMA N 1 Muara Bungo jurusan IPA mengatakan bahwa"... upayanya adalah memberi penjelasan kepada siswa/siswi XII terhadap contohcontoh soal yang akan di UN kan sampai benar-benar mengerti".

Pada kesempatan lain Dani Saputra siswa SMA N 1 Muara Bungo jurusan IPA mengatakan bahwa "..sekolah selalu berupaya memberikan semangat dan motivasi untuk mengikuti kegiatan belajar tambahan".Pendapat yang serupa juga disampaikan oleh Mega Marina Yusuf siswi SMA N 1 Muara Bungo jurusan IPA mengatakan bahwa"... upaya yang dilakukan kepala sekolah dan guru adalah memberikan semangat dan motivasi untuk mengikuti kegiatan belajar tambahan". Pendapat serupa juga disampaikan oleh Reka Dinita Putri siswi SMA N 1 Muara Bungo jurusan IPA mengatakan bahwa"... upaya yang dilakukan kepala sekolah dan guru adalah memberikan semangat dan motivasi untuk mengikuti kegiatan belajar tambahan". Pendapat yang sama juga disampaikan oleh Dini Alvionita siswi SMA N 1 Muara Bungo jurusan IPA mengatakan bahwa "...upaya yang dilakukan kepala sekolah dan guru adalah memberikan semangat dan motivasi untuk mengikuti kegiatan belajar tambahan".

\section{SIMPULAN}

Kebijakan kepala sekolah dalam meningkatkan kualitas sebagai perannya sebagai edukator kelulusan siswa antara lain : melaksanakan proses belajar mengajar secara rutinitas, penilaian secara rutinitas, mengadakan belajar tambahan, melaksanakan kegiatan Try Out. Hambatan yang dihadapi kepala sekolah dalam meningkatkan kualitas kelulusan siswa adalah : Pendanaan, Sumber daya Manusia, Kurangnya motivasi siswa untuk mengikuti kegiatan belajar tambahan, Siswa kurang serius mengikuti kegiatan belajar tambahan. Upaya yang dilakukan kepala sekolah dalam meningkatkan kualitas kelulusan siswa, antara lain : membuat kartu control siswa/siswi yang ikut kegiataan les sore, 
memotivasi siswa akan pentingnya kegiatan belajar tambahan, membuat program pembelajaran yang kreatif, inovatif, dan kondusif, menggalang dana dari wali murid.

\section{DAFTAR PUSTAKA}

Agustina Hanafi dan Indrawati Yuliani. (2006). Faktor-faktor yang mempengaruhi kinerja guru matematika dalam pelaksanaan kurikulum berbasis kompetensi (KBK) pada Sekolah Menengah atas Kota Palembang. Manajemen Dan Bisnis, 4(7), 1-19.

Arikunto, Suharsimi. 2004. Dasar-Dasar Supervisi. Jakarta: Rineka Cipta.

A.R., A., Manarus, R., \&Sidik, H.1996. Hubungan Supervisi Kepala Sekolah Dengan Kepuasan Kerja Guru Sekolah Dasar. Jurnal Ilmu Pendidikan, 3(3), 189-199.

Ancok, Djamaludin. 2012. Psikologi Kepemimpinan dan Inovasi. Jakarta: Erlangga.

Barinto, 2012. Hubungan Kompetensi Guru Dan Supervisi Akademik dengan kinerja Guru SMP Negeri Se-Kecamatan Percut Sei Tuan. Jurnal Tabularasa PPS UNIMED. Vol.9 No.2,201-214

Ekosiswoyo, R. (2007). Kepemimpinan kepala sekolah yang efektif kunci pencapaian kualitas pendidikan. Jurnal IImu Pendidikan, 14(2), 76-82. Retrieved from https://media.neliti.com/media/publications/113918-ID-kepemimpinan-kepala-sekolah-yangefektif.pdf

Husaini Usman, N. E. R. (2013). Strategi Kepemimpinan Pembelajaran Menyongsong Implementasi Kurikulum 2013. Cakrawala Pendidikan, 1, 1-13.

Indonesia, P. R. (2005). RPP_SNP_24 April_2005 1, 1-46.

Karweti, E. (2010). Pengaruh Kemampuan Manajerial Kepala Sekolah Dan Faktor Yang Mempengaruhi Motivasi Kerja Terhadap Kinerja Guru SLB Di Kabupaten Subang. Jurnal Penelitian PendidikanVol, 11(2), 77-89. Retrieved from http://jurnal.upi.edu/file/7-Engkay.pdf

Kerja, M., Kinerja, T., Di, G., Disdikpora, U. P. T., Mayong, K., \& Jepara, K. (2013). JMP, Volume 2 Nomor 1, April 2013, 2(April), 84-91.

Muh. Fitrah. (2017). Peran Kepala Sekolah Dalam Meningkatkan Mutu Pendidikan. Jurnal Penjaminan Mutu Lembaga Penjaminan Mutu Institut Hindu Dharma Negeri Denpasar, 3(1), 31-42.

Purwanti, Sri. 2013. Peran Kepemimpinan Kepala Sekolah Dalam Meningkatkan Disiplin Kerja Guru Dan Pegawai Di SMA Bakti Sejahtera Kecamatan Kongbeng Kabupaten Kutai Timur. eJournal Administrasi Negara. 1(1), 201-224.

Rosyada, Dede.2015. Creative Thingking. Kolom Rektor UIN Syarif Hidayatullah Jakarta, Edisi 3.

Rusmawati, V. (2013). Peran Kepemimpinan Kepala Sekolah Dalam Upaya Meningkatkan Disiplin Kerja Guru Pada Sdn 018 Balikpapan. eJournal Administrasi Negara, 1(2), 395-409.

Sabirin.2012. Perencanaan Kepala Sekolah Tentang Pembelajaran. Jurnal Tabularasa PPS UNIMED, 9(1),111-128.

Saragih, A. H. (2008). Kompetensi Minimal Seorang Guru Dalam Mengajar. Jurnal Tabularasa, 5(1), 23-34.

Sunarto.2011. Pengaruh Gaya Kepemimpinan Kepala Sekolah dan Iklim Organisasi Terhadap Kepuasan Kerja dan Kinerja Guru SMP Di wilayah Sub Rayon 04 kabupaten Demak. Jurnal Analisis Manajemen, 5(1), 17-29.

Suti, M. (2011). Strategi Peningkatan Mutu di Era Otonomi Pendidikan. Jurnal MEDTEK, 3, 1-6.

Retrieved from https://s3.amazonaws.com/academia.edu.documents/35942976/Jurnal_Pak_Marsus_Suti.pdf? AWSAccessKeyld=AKIAIWOWYYGZ2Y53UL3A\&Expires=1530176332\&Signature=NQm30Bw nYqkiV62072oEEu9V1ZE\%3D\&response-content-disposition=inline\%3B filename\%3DJurnal_Pak_Marsus_Suti.pd 